\title{
Immunomodulatory effects of berberine on Staphylococcus aureus-induced septic arthritis through down-regulation of Th17 and Treg signaling pathways
}

\author{
Ailijiang Asila, Jie Liu, Jing Liu, Leijiang Li and Jun Liao® \\ Department of Orthopaedics, Traditional Chinese Medicine Hospital of Xin Jiang, Urumchi, Xinjiang, 830000, China
}

\begin{abstract}
Objectives: The preseaant study was aimed to investigate the immunomodulatory effects of berberine on Staphylococcus aureus-induced septic arthritis through the downstream signaling mechanism of Th17 and Treg, in the control and prevention of disease progression of Staphylococcus aureus induced septic arthritis of blood, spleen and synovial joints. Methods: The study was conducted in mice induced with septic arthritis by S. aureus for 15 days. The infected mice were treated with berberine $(50$ or 100 or $200 \mathrm{mg} / \mathrm{Kg}$ ) to evaluate the effects on the isolated cells of Th17 and Treg from synovial joints,
\end{abstract} blood and spleen against the septic arthritic induced mice followed by JNK, RANKL and NF-KB expressions in the lysates of Th17 and Tregs isolated cells. The evaluation of serum IL-21 and TGF- $\beta$ levels was also conducted after 15 days post-infection in Th17 and Treg population. Results: Our findings showed that berberine exerted excellent inhibitory effects on the S. aureus (AS-789) strain for inducing sepsis-induced arthritis. The results from the $S$. aureus testing revealed that at concentrations below $640 \mu \mathrm{g} / \mathrm{mL}$, the strain was more resistant to berberine, as it had an increased rate of growth. The assessment of S. aureus induced septic arthritis (joint swelling and arthritis index) substantial reduction in the joint swelling and arthritis index $(p<0.01)$ in the berberinetreated groups. The percentage of Th17 cells with CD4 and RORyt; Treg cells with CD4, CD25 and FOXp3 in the synovial joints, blood and spleen was substantially declined in the drug-treated groups $(p<0.01)$ as compared to the $S$. aureus infected mice. The TGF- $\beta$ and IL-21 serum levels determinations in $S$. aureus induced septic arthritis revealed a substantial decrease in serum TGF- $\beta$ levels $(p<0.01)$ in drug-treated groups compared to the infected animals. The post hoc test revealed a substantial decrease in JNK, NF-KB and RANKL expressions in the lysates of Th17 and Treg isolated cells in the drug-treated animals $(p<0.01)$ when compared to the $S$. aureusinfected cluster. Conclusion: Our findings demonstrated that a possible strategy for combating disease severity with berberine treatment in Staphylococcus aureus induced septic arthritis in mice, which targets the Th17 and Treg cells have driven the NF-KB/JNK-RANKL axis.

Keywords: Berberine, S. aureus, Treg cells, septic arthritis

Received: 09 October, 2021; revised: 07 November, 2021; accepted: 13 November, 2021; available on-line: 22 January, 2022

凶e-mail: junliao@yahoo.com; xjlj605@163.com

Acknowledgements of Financial Support: This study was supported by the National Natural Science Foundation of China (No. 81760875)

Abbreviations: AhR, Aryl hydrocarbon receptor; CMC, Carboxymethyl Cellulose; CYP1A1, Cytochrome P450, family 1, subfamily A;
EDTA, Ethylenediaminetetraacetic acid; FACS, Fluorescence-activated cell sorting; FOXP3, Forkhead box P3 protein; IFN- $\gamma$, Interferongamma; IL-21, Interleukin-21; IKB, Inhibitor of nuclear factor kappa $\mathrm{B}$; JNKC, Jun N-terminal Kinase; MAPK, Mitogen-activated protein kinase; MHB II, MuellerHinton broth II; MIC, Minimum inhibitory concentration; NF-kB, Nuclear factor kappa B; RANKL, Receptor activator of nuclear factor kappa-B ligand; RORyt, Transcription factors of the RAR-related orphan nuclear receptor (ROR) family; S. aureus, Staphylococcus aureus; TBST, Tris Buffered Saline with Tween; TGF- $\beta$, Transforming growth factor; Th2 cells, T helper T2 cells; Treg cells, Regulatory T cells; TSB, Tryptic soy broth

\section{INTRODUCTION}

Septic arthritis is typically characterized by a swollen and inflamed joint (Carpenter et al., 2011). Septic arthritis remains a significant problem due to its high death and morbidity rates (Shirtliff \& Mader, 2002). T cells and their subsets are critical for the integration of the innate and adaptive immune systems in numerous diseases in regulating disease severity. The $\mathrm{T}$ cells and cytokines perform a major function in the control and progression of Staphylococcus aureus septic arthritis. The Staphylococcal superantigen induces an influx of immune cells, particularly PMNs and macrophages, as well as significant T-cell (CD4+) infiltration (Abbas et al., 1996) (Colavite-Machado et al., 2013). The CD4 and T-helper cells differentiate into many sub-types after being exposed to antigens. Th17 cells are vital in the pathogenesis of many autoimmune and infective illnesses (Beringer et al., 2014). These Th 17 cells grow independently of CD4 and T-helper cells and involve TGF- $\beta$ and IL- 6 produced by active immune cells to grow (Kimura \& Kishimoto, 2010). The Th17 cells may produce pro-inflammatory cytokines such as IL-21, -17A and -17F (Lubberts, 2010).

The expression of ROR $\gamma t$ and subsequent stabilization of Th17 cells exacerbate disease conditions following the IL-21R upregulation on the stimulated Th17 cells (Huber et al., 2008). These Th17 cells are known to play a role in several arthritic models (Kugyelka et al., 2016). The homotypic binding of IL-17A and its receptors cause osteoclast differentiation via the MAPK and NFxB pathways (Ichiyama et al., 2011; Ruan \& Chen, 2012).

It also activates RANKL, which promotes osteoclast production in the synovial joint, resulting in bone loss (Chen et al., 2016). The Th17 and T-regulatory cells formed from undistinguishable CD4 and T cells have distinct relationships with the existence of TGF- $\beta$ (Kong et al., 2012). The ability to tolerate endogenous proteins conferred by FoxP3 expression aids in the control of immunogenic inflammation (Fontenot et al., 2003).

Many strategies have been used to exploit Tregs' immunosuppressive properties, including several arthritis models (Grant et al., 2015). In many cases, an abnormal 
Th17/Treg balance is linked to poor prognosis (Noack \& Miossec, 2014). Inducible transcription factors control the progress, purpose of inflammatory and regulatory $\mathrm{T}$ cells. NF- $x \mathrm{~B}$, a central mediator of many inflammations, is activated via two main pathways: non-canonical and canonical (Sun, 2011; Vallabhapurapu \& Karin, 2009; Oh \& Ghosh, 2013). The NF- $x \mathrm{~B}$ expression changes were linked to increased IL- 6 production, a major mediator of Th17 differentiation (Chang et al., 2009). Also, ablating T cell-specific IKK reduced Th17 induction, demonstrating NF-regulatory B's role in modulating Th17 responses in autoimmune disorders like experimental allergic encephalomyelitis (Greve et al., 2007). The paradoxical role of $\mathrm{NF}-x \mathrm{~B}$ in the immune response is revealed by its ability to stimulate inflammatory genes while regulating Tregs. c-Rel is linked to both Th17 and Treg formation via its master transcription factor FoxP3 (Long et al., 2009; Ruan et al., 2009). NF-xB members such as $\mathrm{I} x \mathrm{~B}$ have been shown to influence Treg proliferation and function, which is disrupted in these conditions (Chang et al., 2012; Shi \& Sun, 2015) T cell differentiation is closely linked to NF- $x \mathrm{~B}$ and MAPK transcription factors. The MAPK genealogy consists of ERK, JNK, and p38 kinase. Inhibition of $\mathrm{T}$ cell proliferation, differentiation, and death by JNK family protein kinases (Dong et al., 2000)). ROR $\gamma \mathrm{t}$ expression increases in pathogenic Th17 cells with IL-6 (Sato et al., 2006; Kikuta et al., 2013).

These activated Th17 cells then produce IL-17, which increases JNK activation (Li et al., 2016; Li et al., 2016). The role of TGF- $\beta$ in Treg generation from naive CD4+Th cells is not limited to the differentiation of Th17 cells. It assists in the adaptation of Treg differentiation via SMAD independent MAPK pathways, involving JNK/ERK, but without including p38 (Lu et al., 2010; Zhang, 2009). JNK inhibition impeded TGF- $\beta$ mediated Treg proliferation in mice (Dominguez-Villar \& Hafler, 2018; Arellano et al., 2016; Somayaji et al., 2008; Henningsson et al., 2010). TGF- $\beta$ also activates JNK, increasing FoxP3 expression in Tregs, which has been linked to a reduction in disease severity. Th17 stimulates osteoclastogenesis via the RANK-RANKL axis, as well as $\mathrm{NF}-x \mathrm{~B}$ and JNK signaling pathways (Dominguez-Villar \& Hafler, 2018; Lu et al., 2010). RANKL is an osteoclastogenic factor expressed by macrophages, synovial fibroblasts, CD4+T cells and osteoblasts (Arellano et al., 2016). Bone injury is mediated by RANK-RANKL interaction (Somayaji et al., 2008). Local IL-17 overexpression was corresponding along the higher RANKL expression in collagen-induced arthritis animals (Henningsson et al., 2010). Also, Th17-particular mediators like IL-6, IL-1, and TNF cause bone loss via a RANKL-dependent mechanism (Takayanagi, 2005). The RANKL/NFB axis causes significant bone injury and the development of inflammatory arthritis (Kikuta et al., 2013; Sato et al., 2006).

Natural compounds like Berberine have been studied for their pharmacological benefits, especially in the treatment of cancer, diabetes, atherosclerosis, and cardiovascular diseases (Cicero \& Baggioni, 2016; Fatahian et al., 2020; Kumar et al., 2015; Ayati et al., 2017; Hu et al., 2011; Mortazavi et al., 2020). The antimicrobial outcome of berberine was tested against staphylococcus (coagulase-negative) strains by Zhou and others (Zhou et al., 2019). Berberine, which was studied by Chu and others (Chu et al., 2016) showed antibiotic activity against Methicillin-Resistant S. aureus (Moreland \& Curtis, 2009). According to Guo and others (Guo et al., 2015), berberine was found to be efficient in preventing $S$. aureus growth in the biofilm cultures. These investigations, yet, used strains that were either non-clinical or not $S$. aureus strains.

Berberine therapy reduced collagen-stimulated splenocytes' producing inflammatory cytokines IFN- $\gamma$, IL-2, and IL-17 and increased joint stiffness in both collageninduced arthritis (Wang et al., 2014; Yue et al., 2017) and Autoimmune and Autoinflammatory Arthritis (Wang et al., 2014) models. Berberine also lowered down bone loss, enhanced calcium restoration in AIA rats by inhibiting osteoclast proteolytic activity and lowering RANKL released in the joint area (Sujitha et al., 2020). Berberine's suppressive impact on bone erosion is subsequently confirmed, demonstrating inhibition of RANKL-related osteoclastogenic differentiation by suppressing $\mathrm{NF}-\varkappa \mathrm{B}$ and Akt stimulation (Dinesh \& Rasool, 2018; Hu et al., 2008). Many in vitro and in vivo investigations have shown that berberine has modulatory effects on Th17 and Treg cell function and proliferation in rheumatoid arthritis (Dinesh \& Rasool, 2019). Berberine reported to drastically lower Th17 population blood levels and IL17 serum levels in collagen-induced arthritis in rats. This effect is followed by a decrease in the synovium IL-17 expression and ROR $\gamma \mathrm{t}$ (Th17 transcription factor) in the spleen. Berberine therapy can drastically reduce Th17 cell development according to an in vitro study on naive $\mathrm{T}$ cells isolated from the spleen of autoimmune and autoinflammatory arthritis in rats, by down-regulating CD196 and ROR $\gamma$ t. Consequently, berberine treated naive CD4 and $\mathrm{T}$ cells demonstrated development of CD4, CD25 and Foxp3 in Treg cells via the AhR/CYP1A1/Foxp3 axis (Dinesh \& Rasool, 2019).

However, no research examining the immunomodulatory effects of berberine on staphylococcus aureus-induced septic arthritis including downregulation of Th17, Treg signaling pathways have been published so far. The berberine's immunomodulatory effects on staphylococcus aureus-induced septic arthritis were investigated through the downregulation of Th17 and Treg, in regulating the pathogenesis of $S$. aureus-induced septic arthritis. Additionally, the study examined the immunomodulatory effects of berberine on the various downregulating signaling pathways of Th17 and Treg cells obtained from arthritic mice's synovial joints, blood, and spleen.

\section{MATERIALS AND METHODS}

\section{Animals}

Adult male mice (Swiss albino; $25 \pm 2 \mathrm{~g}$ ) were utilized in this experiment, and faunas were preserved in a controlled setting (temperature $25 \pm 3^{\circ} \mathrm{C}$ ). The animal ethical committee permitted the use of animals (approval number: TCM-JL_12/45/2020). The experimental mice were given a standard mouse meal and free clean water. After 15 days, mice were segregated into control and S. aureus infected groups. The $S$. aureus affected category was further segregated into three subdivisions: Berberine (50 or 100 or $200 \mathrm{mg} / \mathrm{Kg}$ )). Each subgroup consisted of ten mice.

\section{Culture of Staphylococcus aureus}

Staphylococcus aureus was employed in this investigation, and it was procured from the Hospital in Beijing (AG-789; S. aureus-strain). The bacteria were kept in our $\mathrm{lab}$ and their antibiotic sensitivity was examined. Clinical isolates of this strain were utilized in previous animal models of arthritis to induce a non-lethal infection 
temporarily (Dey \& Bishayi, 2017). The bacterial isolates were incubated and washed using sterile PBS, and the inoculum was assessed using a spectrophotometer and the optical density was adjusted before infection (Optical Density $600=0.3=4 \times 10^{6}$ cells $/ \mathrm{ml}$ for $S$. aureus) (Dey \& Bishayi, 2020).

\section{The minimum inhibitory concentration (MIC) of berberine}

The MIC values of berberine against $S$. aureus strain (AG-789) were evaluated in triplicate using two-fold dilution series in MHB II (Mueller-Hinton broth II) as described before (Dey \& Bishayi, 2017; Dey \& Bishayi, 2020). The minimum inhibitory concentrations (MICs) were determined as the minimum concentrations at which no observable increase was seen after 24 hours. Berberine was added to a 96-well plate of TSB broth containing $1 \%$ glucose to make $100 \mu \mathrm{l}$ as a final volume, and concentrations $(5,10,20,40,80,120,160$, 320 , and $640 \mu \mathrm{g} / \mathrm{ml}$ ) were prepared. The subsequent inoculation of cultures was carried out with $200 \mu \mathrm{l}$ of $S$. aureus seeded culture $\left(6 \times 10^{5} \mathrm{CFU} / \mathrm{mL}\right)$. The supernatant was entirely removed after incubation for 24 hours at $37^{\circ} \mathrm{C}$, the wells were washed 3-4 times with phosphatebuffered saline (PBS) ( $\mathrm{pH}$ 7.4). The biofilm was then stabilized for 20 minutes with $150 \mu$ methanol before being dried at $50^{\circ} \mathrm{C}$. The biofilm was then stained for 20 minutes with $220 \mu \mathrm{l}$ of 0.2 percent crystal violet. PBS was used to rinse unbound crystal violet 3 times. Following drying, $300 \mu \mathrm{L}$ of ethanol $(90 \%)$ was introduced to the wells, and the plates were agitated to remove the stains from the biofilm for about 2 hours. The biofilm's absorbance was calculated three times at $600 \mathrm{~nm}$. The bacterial growth control was performed using wells containing 1\% DMSO, bacteria.

\section{Bacterial growth control assessment}

In 96-well plates, a suspension of $200 \mu \mathrm{L}$ bacterial cultures $\left(4 \times 10^{5} \mathrm{CFU} / \mathrm{mL}\right)$ in Tryptic soy broth (TSB) was introduced to $200 \mu \mathrm{L}$ of serial dilutions of berberine (5, $10,20,40,80,120,160,320$, and $640 \mu \mathrm{g} / \mathrm{mL})$. Microplates were cultivated at room temperature for $3,6,12$, and 24 hours, and bacterial growth was assessed using a microplate reader to measure the optical density at 620 $\mathrm{nm}$ wavelength. the wells comprising $1 \%$ DMSO and a bacterial inoculum represented as a control for bacterial growth.

\section{Procedure for S. aureus induced arthritis}

The methodology from our prior findings was used to generate septic arthritis in mice (1:2). The mice were given sterile phosphate $(100 \mu \mathrm{L})$ buffered saline (PBS) comprising $S$. aureus inoculum through the tail vein. The control mice were given sterile PBS $(100 \mu \mathrm{L})$. Each group was monitored regularly $\left(4 \times 10^{7} \mathrm{CFU}\right.$ per mouse) for 15 days.

\section{Treatment of drugs}

After 15 days, the $S$. aureus diseased group was separated into three subgroups: Berberine 50 or 100 or 200 $\mathrm{mg} / \mathrm{Kg}$ ). Each subgroup consisted of ten mice. Gavage was used to administer the drug substances orally. Before oral administration, the drug substances were suspended in 10\% CMC. Each of the three infected groups received medicines orally for 15 days after the infection period of fifteen days.

\section{S. aureus induced septic arthritis evaluation}

A Vernier calliper was used every day to check the oedema of the mice's paws, ankle joints, and synovial knee joints. The severity of joint swelling was represented by these average values (Bettelli et al., 2008) Induction $(\%)$ of arthritis in each group of treated and untreated mice was computed as: (Mean diameter (synovial knee joint swelling) in $S$. aureus infected mice on 15 th day Mean diameter (synovial knee joint swelling) in control mice on 15th day)/Mean diameter (synovial knee joint swelling) in control mice on 15th day) multiplied by 100 . The significant differences noticed in the joint swelling reduction between the groups were evaluated statistically. The clinical severity of paw swelling due to arthritis was rated on a scale from 0 to 3 according to the modifications observed in swelling and erythema for each paw (0 - no modification; 1 - mild erythema and swelling; 2 moderate erythema and swelling; 3 - marked erythema, swelling, and ankylosis). To calculate the arthritis index, the overall score was divided by the no. of fauna's putto-use under each category (Puliti et al., 2002).

\section{Collection of specimens}

The control, S. aureus infected, and drug-treated mice were anaesthetized with inhalation anaesthetics (ether) on the scheduled days after infection. General anaesthesia with anaesthetic ether was used for euthanasia, which was followed by tissue removal for further processing. A cardiac puncture was used to collect blood $(1 \mathrm{~mL})$, following the spleens and synovial tissues isolation.

\section{Lymphocyte isolation from blood}

Blood was extracted after euthanasia to mice through heart puncture and accumulated in precoated heparin micro-centrifuge tubes $(100 \mu \mathrm{L})$. The blood collected was then diluted with the same amount of phosphate buffer saline $(1: 2)$ and centrifuged at $1000 \times g$ for $30 \mathrm{~min}$ utes. The lymphocyte film was isolated and then rinsed with phosphate buffer saline after centrifugation (Mizobe et al., 1982). Isolated lymphocytes from each mouse were accumulated in a centrifuge $(15 \mathrm{~mL})$ tube, revamped into microcentrifuge tubes containing fluorochrome-conjugated antibodies for fluorescence-activated cell sorting. Experiments were done in triplicate.

\section{Spleen lymphocytes isolation}

Spleens were homogenized in an ice bath with Alsever's solution for the collection of splenic lymphocytes. Isolation of lymphocytes was achieved using single-cell suspension via repeatedly aspirating tissue above lymphocyte separation media in a 3:2 ratio and afterwards centrifuged at $1000 \times \mathrm{g}$ for 30 minutes. To remove adherent cells, isolated cells were cultured for one hour at room temperature with $5 \% \mathrm{CO}_{2}$ in an incubator before being washed with RPMI-1640 medium. Lymphocytes were categorized as non-cells (Johansen et al., 1974). Lymphocytes were extracted from the spleens of ten mice and pooled in a centrifuge $(15 \mathrm{~mL})$ tube before being reallocated in 3 microcentrifuge tubes containing fluorochrome antibodies for fluorescence-activated cell sorting (FACS).

\section{Synovial joint lymphocyte isolation}

The synovial joints were isolated from the hind paws of the infected and control mice. The isolated joints were treated individually with $4 \mathrm{mg} / \mathrm{mL}$ of collagenase- 
$\mathrm{D}$ in phosphate buffer saline for 40 minutes at room temperature. The digestion was then halted by adding EDTA $(10 \mathrm{mM})$ and incubated for another 15 minutes (Rampersad et al., 2011). The transparent cell solution was then placed as layers onto the medium for lymphocyte separation, centrifuged at $4000 \mathrm{rpm}$ for 20 minutes. The lymphocyte layers were later collected as described before. Lymphocytes were extracted separately from both synovial joints of ten mice for each experimental group, were then gathered in $15 \mathrm{~mL}$ capacity centrifuge tubes and transferred into the micro-centrifuge tubes accompanied by the conjugation of fluorochrome antibodies for fluorescence-activated cell sorting.

\section{Antigen staining to assess the ratio of Th17/Treg cells}

Isolated lymphocytes were obtained and collected in micro-centrifuge tubes from the synovial joints, blood and spleen of the control, infected and drugtreated mice for flow cytometric evaluation. Discolouring of several intracellular and extracellular markers was carried out for the separation of Th17 and Tregs as previously described (Dey \& Bishayi, 2017, 2020; Rampersad et al., 2011). Later re-suspension of cells was done in $200 \mu \mathrm{L}$ FACS buffer and stained with the following surface markers: CD4 antibody conjugated with PE-Cy5 (1 $\mu \mathrm{g}$ per $4 \times 10^{6}$ cells) and CD25 antibody conjugated with FITC were added (15 $\mu \mathrm{g}$ per $10^{7}$ cells). Cells were washed and fixed with $3 \%$ formaldehyde after 20 minutes at $4^{\circ} \mathrm{C}$ incubation. We next reconstituted the cells and added intracellular markers to them in a 0.5 percent saponin buffer before resuspending them again: PE-conjugated ROR $\gamma \mathrm{t}$ antibody $\left(0.3 \mu \mathrm{g}\right.$ per $10^{6}$ cells $)$; APC conjugated FoxP3 $\left(0.135 \mu \mathrm{g}\right.$ per $10^{6}$ cells) according to maker's protocol. Cells were rinsed and re-suspended in FACS buffer after 20 minutes. Lymphocytes extracted from control and S.auerus infected mice's synovial joints were treated with surface markers labelled with fluorochrome, accompanied by permeabilization of cells with intracellular labelling. Before acquiring samples with multiple stains, we determined the fluorochrome compensation values using unstained and single fluorochrome stained samples. Plots were generated with CD4+ T cells, and 8000-9000 events were calculated to estimate the fraction of Th17 cells and Treg cells (Wilde et al., 2012).

\section{Preparation of samples for cytokine analysis}

The blood samples were coagulated at $4{ }^{\circ} \mathrm{C}$ before centrifugation at $500 \times \mathrm{g}$ for about 10 minutes to determine serum cytokine levels. The serum supernatant was obtained, kept at $-80^{\circ} \mathrm{C}$, and utilized for the experiment. Before this analysis, all samples from individual groups were standardized for protein content using the Bradford method, and the levels of IL-21 and TGF- $\beta$ were assessed using an ELISA kit (Majhi et al., 2014; Dey \& Bishayi, 2020) following the recommendations of the manufacturer's protocol. The least determining IL-21 and TGF- $\beta$ values were $<7 \mathrm{pg} / \mathrm{ml}$ and $0.61 \mathrm{ng} / \mathrm{L}$ respectively. The intra- and inter-assay reproducibility of IL-21 cytokine kits: CV $<12 \%$ : CV $<15 \%$. The intraand inter-assay reproducibility of TGF- $\beta$ cytokine kits: $\mathrm{CV}<10 \%$ : CV $<12 \%$.

\section{Western blot analysis}

Isolated lymphocytes from synovial joints, blood, and spleen were analyzed using the western blot procedure.
Then, using intracellular (ROR $\gamma$ t and FoxP3) and surface markers (CD4 and CD25) for Th17 and Treg cells, fluorescence-activated cell sorting (FACS) was used to sort Th17 and Treg cells. After lysing, the Th17 and Treg cells in RIPA buffer supplemented with Nonidet P-40, the cell lysates were denatured with an equivalent protein concentration for 10 minutes at $80^{\circ} \mathrm{C}$, re-determined using $10 \%$ SDS PAGE, and transferred onto a nitrocellulose membrane. The blocking buffers containing bovine serum albumin (BSA, 5\%) used were TBST $(15 \mathrm{mM}$ Tris-hydrochloride, $\mathrm{pH} 7.2)$, sodium chloride $(100 \mathrm{mM})$, Tween-20 (0.2\%) at $4^{\circ} \mathrm{C}$ for 3 hours. Membranes were then rinsed thrice with TBST, allowed to conjugate in TBST supplemented BSA $(2 \%)$ overnight with primary antibody (RANKL), NF- $x \mathrm{~B}$ and JNK kinase at $4^{\circ} \mathrm{C}$. The blots were washed three times with TBST at $4^{\circ} \mathrm{C}$ with HRP conjugated secondary antibodies for about 3 hours. The chemiluminescent-substrate was used to generate the final signal. Each blot was then quantified with BioRad Software.

\section{Statistical analysis}

Each group's outcomes were expressed as mean \pm S.D. $(\mathrm{n}=10)$. A one-way study of variance was utilized to assess significant variations between clusters (ANO$\mathrm{VA}$ ). One-way ANOVA was used to determine whether there were significant differences in the means among the groups, following Dunnett's $t$-test with $p<0.05$ as statistically significant for the outcomes.

\section{RESULTS}

\section{Berberine exerted excellent inhibitory effects on S. aureus (AS-789) strain for inducing sepsis-induced arthritis}

There was a range of MIC values for berberine from 80 to $640 \mathrm{~g} / \mathrm{ml}$. The MIC value for the highest strain was $640 \mathrm{~g} / \mathrm{ml}$, while the minimum was 80 $\mathrm{g} / \mathrm{ml}$. There was no substantial growth of the tested $S$. aureus after 2 hours of incubation (Fig. $1 \mathrm{a}$ and b). When compared to the control group after six hours of incubation, the trial strain depicted a considerable reduction in the total count of bacteria (as demonstrated via variations in OD value) (1 percent DMSO, Fig. 1c). A substantial decline in the proportion of bacteria, with total growth inhibition of the strain, was noted after incubation for 12 hours with a range of berberine concentrations starting with 40 and at maximum $640 \mu \mathrm{g} / \mathrm{mL}$ (Fig. 1d). Despite some growth, the number of microbes in the range of berberine concentrations from 40 to $640 \mathrm{~g} / \mathrm{mL}$ decreased significantly after 24 hours. The bacteria stopped growing completely when the concentrations of 320 and 640 $\mu \mathrm{g} / \mathrm{mL}$ were reached, and the OD value remained the same (Fig. 1e). The results from the $S$. aureus testing revealed that at concentrations below $640 \mu \mathrm{g} / \mathrm{mL}$, the strain was more resistant to berberine, as it had an increased rate of growth.

\section{Assessment of Staphylococcus aureus-induced septic arthritis (joint swelling and arthritis index)}

Induction of arthritis was assessed in control, infected and drug-treated mice from the swelling of the synovial joints. The research discovered that infected mice had greater joint size, which began to expand over time, starting from day 0 to day 15 . Infected mice showed the 

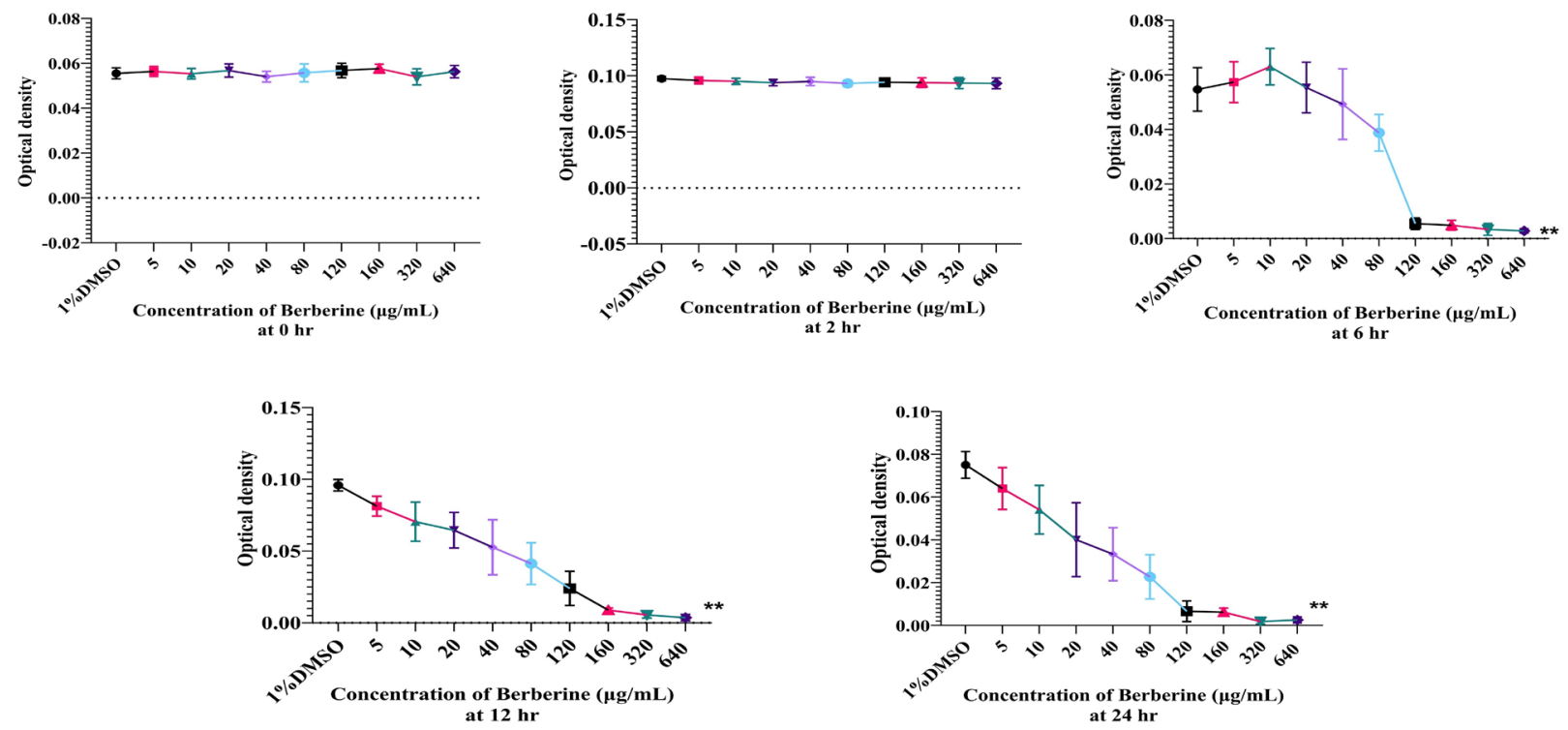

Figure 1. Growth kinetics of clinical S. aureus in the presence of different berberine concentrations after incubation of $0 \mathrm{~h}$ (a); $2 \mathrm{~h}$ (b); $6 \mathrm{~h}(\mathrm{c}) ; 12 \mathrm{~h}(\mathrm{~d})$ and $24 \mathrm{~h}(\mathrm{e})$
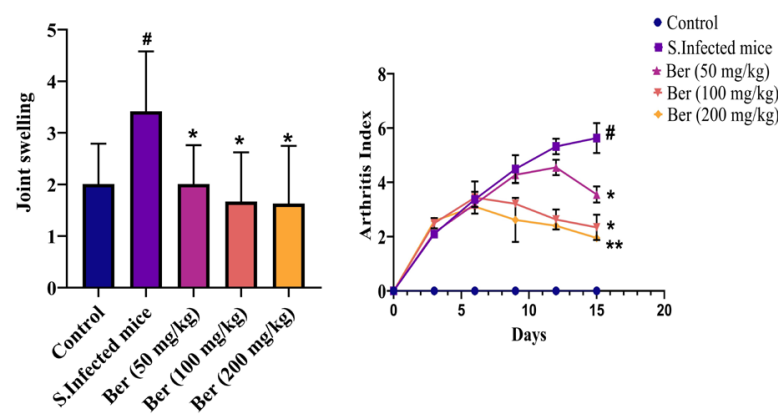

Figure 2. Experimental evaluation of joint swelling and arthritis index in S. aureus infection induced arthritis at different berberine (Ber) at 50, 100 and $200 \mathrm{mg} / \mathrm{kg}$.

Values were expressed as mean \pm S.D. of six mice per group $(p<0.05)$. \#indicates significant difference in comparison to control group. ${ }^{*} p<0.05$ and ${ }^{* *} p<0.01$ indicates significant difference in comparison to infected groups.
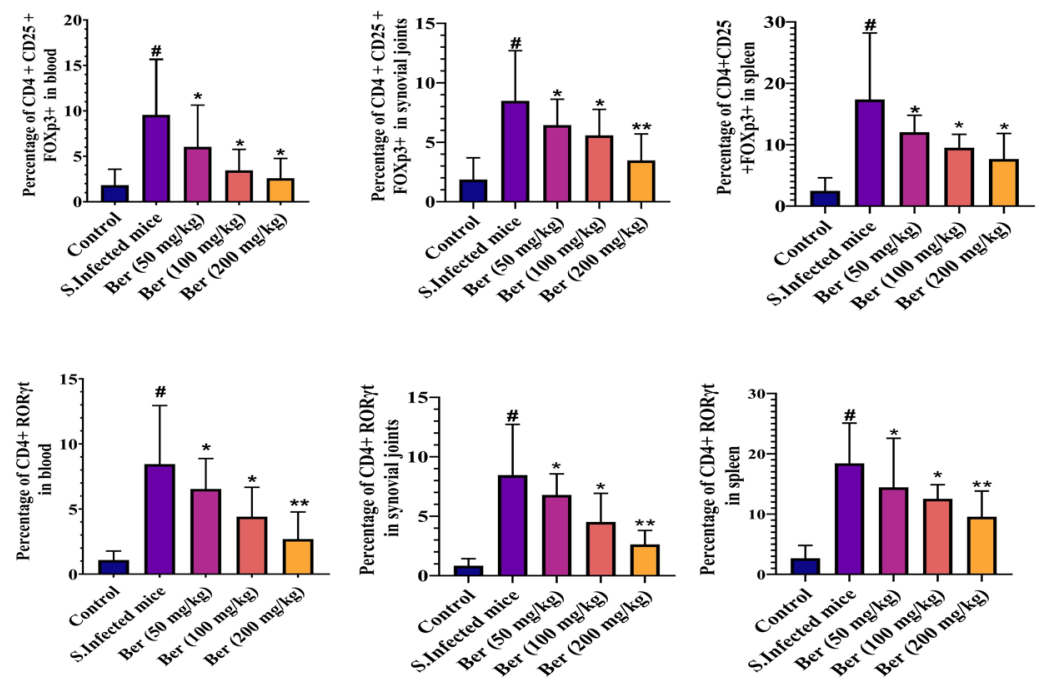

Figure 3. Percentage of FACS Sorted CD4+RORyt+Th17 cells and CD4+CD25+FoxP3+Treg cells in Blood, Spleen and Synovium in control, $S$. aureus infected and berberine treated mice.

Percentage of lymphocytes were expressed as mean \pm S.D. of six mice per group $(p<0.05)$. \#indicates significant difference in comparison to control group. ${ }^{*} p<0.05$ and ${ }^{* *} p<0.01$ indicates significant difference in comparison to infected groups. 

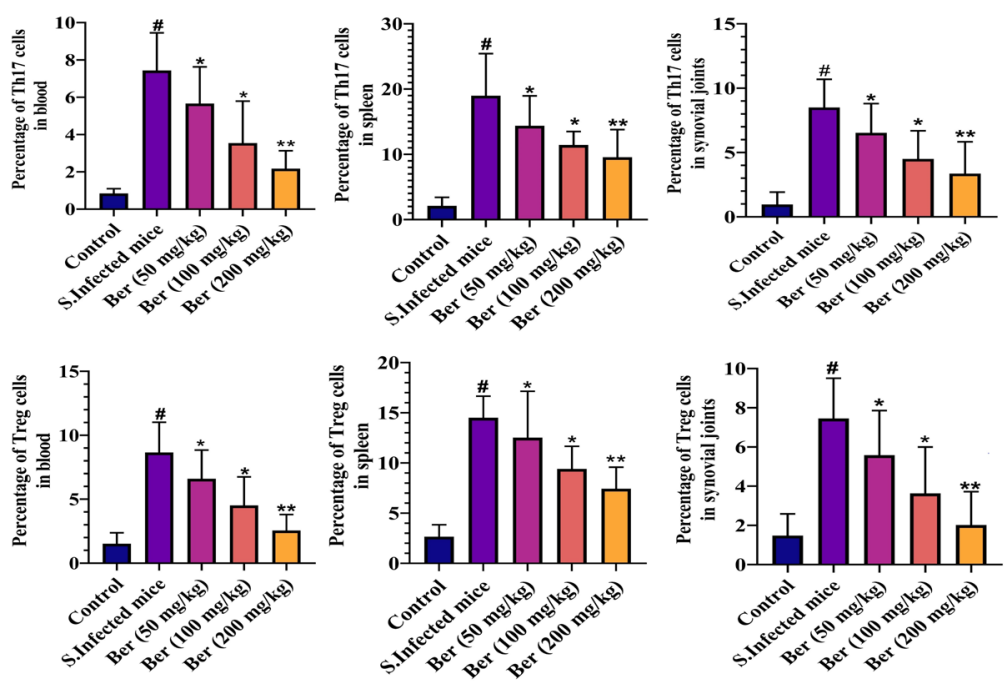

Figure 4. Graphical representation of percentage of Th17 and Treg cells isolated by FACS from Blood, Spleen and Synovial joints in Control, S. aureus infected and Berberine treated mice and collective analyses of Th17 cells (expressed as \% cells) sorted from whole lymphocyte population obtained from blood, spleen and synovial joints.

Values were expressed as mean \pm S.D. of six mice per group $(p<0.05)$. \#indicates significant difference in comparison to control group. ${ }^{*} p<0.05$ and ${ }^{* *} p<0.01$ indicates significant difference in comparison to infected groups.

Analysis of flow cytometry to determine the percentage of Th17 cells with CD4 and RORyt and Treg cells with CD4, CD25 plus FOXp3 in the synovial joints, spleen and blood

The control, S. aureus-infected and drug-treated mice septic were given different extracellular and intracellular markers to extract Treg and Th17 cells from the synovial joints, spleen and blood to assess the modification in Th17 and Treg cells (Fig. 3). The clarity of insulated Th17 and Treg cells post arranging was higher than 97 percent in each sample. The percentage of Th17 cells in blood was considerably higher in the diseased cluster relative to the uninfected group. The amount of Th17 cells in the infected group increased significantly $(p<0.01)$ after 15 days post-infection (Fig. 3). The 15day therapy with berberine (50 or 100 or $200 \mathrm{mg} / \mathrm{Kg}$ ) revealed significant differences among groups, according to a one-way ANOVA analysis. The post hoc analysis reveals a substantial decline in the percentage of Th17 cells in drug-treated groups $(p<0.01)$ as compared to the $S$. aureus infected mice.

The $S$. aureus infected group (CD4+, CD25+, FoxP3+, Treg cells) had more of a Treg population than the control group due to a considerable rise in the number of infected Treg cells in the infected group. The post-infection Treg population was observed to grow sharply after
15 days (Fig. 3). The one-way ANOVA analysis revealed significant differences between groups after 15 days of therapy with berberine (50 or 100 or $200 \mathrm{mg} / \mathrm{Kg}$ ). The post hoc test revealed a substantial decrease $(p<0.01)$ in the number of CD4+; CD25+; FoxP3+ and Treg cells in the drug-treated groups compared to the infected group.

The population of Th-17 was enhanced among the sick animals after fifteen days of post-illness when compared to control animals in the case of splenic $\mathrm{T}$ lymphocytes (Fig. 4). The Treg population of the spleen in infected animals had a considerably higher population than that of the control group. The one-way ANOVA study of the berberine (50 or 100 or $200 \mathrm{mg} / \mathrm{Kg}$ ) treatments for 15 days revealed notable differences among groups. The post hoc test revealed a substantial decrease in the number of splenic $\mathrm{T}$ lymphocytes (Th17) and splenic Treg population $(p<0.01)$ in drug-treated groups compared to infected animals.

The Th17 cells were observed to be more prevalent in infected synovial joints than in the control group. Th17 cells were most abundant during 15 days of post-infection (Fig. 4). The percentage of Treg cells was also dramatically enhanced after 15 days post-infection (Fig. 5). The 15-day treatment with berberine (50 or 100 or $200 \mathrm{mg} / \mathrm{Kg}$ ) revealed important changes between groups when studied using one-way ANO-
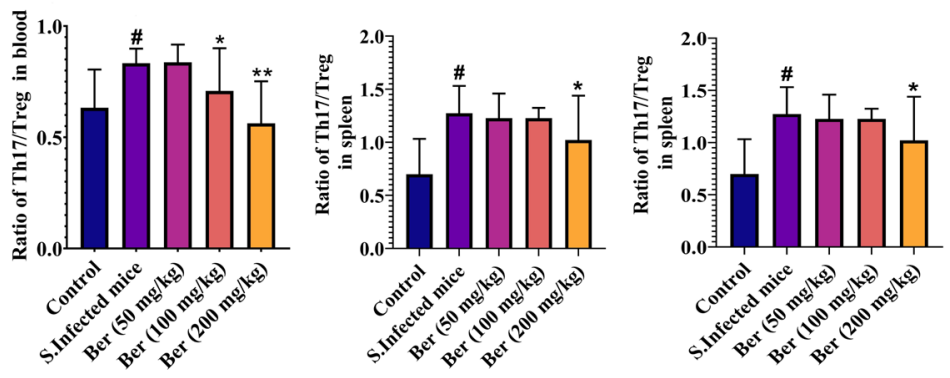

Figure 5. The Th17/Treg cells ratio in Blood, Spleen and Synovium in control, S. aureus infected and berberine treated mice. \#indicates significant difference in comparison to control group. ${ }^{*} p<0.05$ and ${ }^{* *} p<0.01$ indicates significant difference in comparison to infected groups. 


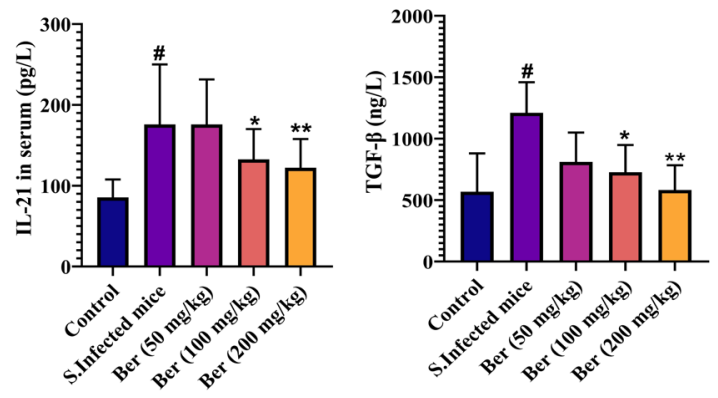

Figure 6. Serum levels of IL-21 and TGF- $\beta$ in control, S.aureus infected and Berberine treated mice.

Values were expressed as mean \pm S.D. of six mice per group $(p<0.05)$. \#indicates significant difference in comparison to control group. ${ }^{*} p<0.05$ and ${ }^{* *} p<0.01$ indicates significant difference in comparison to infected groups.

VA. The after hoc analysis revealed a substantial decline in the number of splenic $\mathrm{T}$ lymphocytes (Th17) and splenic Tregs in synovial joints $(p<0.01)$ in the drug-treated groups equated to the infected cluster.

A fraction of FoxP3 and CD4 of the Treg cells were found in the lymphocytes obtained from synovial joints spleen and blood. The Th17 and Treg ratios were separated during Treg cell gating from lymphocytes indicated a substantial boost in the Th17/ Treg ratio relative to the blood and tissues of control mice (Fig. 5). The one-way ANOVA analysis revealed significant differences between groups after 15 days of therapy with berberine (50 or 100 or $200 \mathrm{mg} / \mathrm{Kg}$ ). The post hoc analysis reveals a substantial drop in the Th17/Treg ratio in the blood and tissues of drugtreated groups $(p<0.01)$ as compared to the infected group (Fig. 4).

\section{Serum TGF- $\beta$ and IL-21 determinations in S. aureus induced septic arthritis}

To measure the amounts of TGF- $\beta$ and IL-21, the serum of the uninfected, infected, and drug-treated mice were collected. The serum level of IL-21 was considerably elevated in the infected set as equated to the uninfected control cluster. The increase in IL-
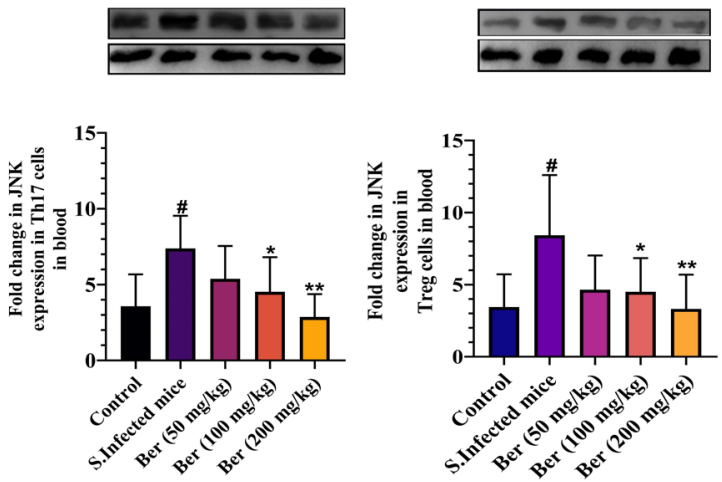

Figure 7. Western blot expression of JNK from lysate of Th17 and Treg cells in blood.

Schematic expression of JNK expression in the FACS isolated Th17 and Treg cells from blood. Respective fold-changes in expression are shown in graph. All membranes were stained with anti-betatubulin antibody to assure equal protein loading in the gels occurred. Expressions of JNK were measured in terms of fold-change compared to control. Experiments were repeated three times with similar results $(p<0.05)$. Values were expressed as means \pm S.D. \#indicates significant difference in comparison to control group. ${ }^{*} p<0.05$ and ${ }^{* *} p<0.01$ indicates significant difference in comparison to infected groups.

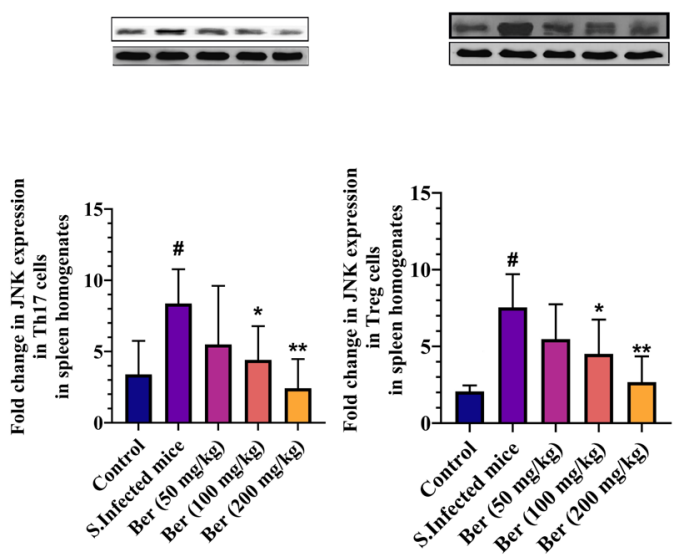

Figure 8. Western blot expression of JNK from lysate of Th17 and Treg cells in spleen homogenates.

Schematic expression of JNK expression in the FACS isolated Th17 and Treg cells from spleen homogenates. Respective fold-changes in expression are shown in graph. All membranes were stained with anti-beta-tubulin antibody to assure equal protein loading in the gels occurred. Expressions of JNK were measured in terms of fold-change compared to control. Experiments were repeated three times with similar results $(p<0.05)$. Values were expressed as means \pm S.D. \#indicates significant difference in comparison to control group. ${ }^{*} p<0.05$ and ${ }^{* *} p<0.01$ indicates significant difference in comparison to infected groups.

21 levels occurred within 15 days following infection in the infected group (Fig. 6). The one-way ANOVA study of the berberine (50 or 100 or $200 \mathrm{mg} / \mathrm{Kg}$ ) treatments for 15 days revealed significant differences between groups. The post hoc test revealed that the drug-treated groups had significantly lower serum levels of IL-21 $(p<0.01)$ than the infected group. The infected group had considerably higher levels of TGF$\beta$ than the control group (Fig. 6). The 15-day therapy with berberine (50 or 100 or $200 \mathrm{mg} / \mathrm{Kg}$ ) revealed significant differences across groups, according to a one-way ANOVA analysis. The post hoc test revealed a substantial decrease in serum TGF- $\beta$ levels $(\phi<0.01)$ in drug-treated groups compared to the infected animals.
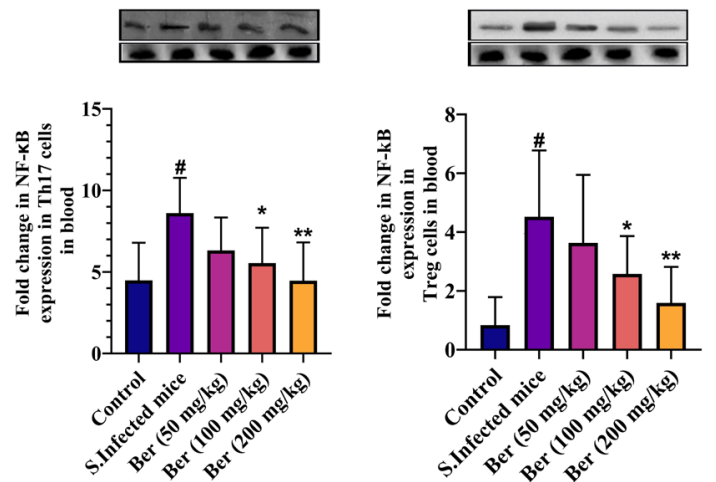

Figure 9. Western blot expression of NF-KB from lysate of Th17 and Treg cells in blood. Schematic expression of NF-KB expression in the FACS isolated Th17 and Treg cells from blood. Respective fold-changes in expression are shown in graph. All membranes were stained with anti-beta-tubulin antibody to assure equal protein loading in the gels occurred. Expressions of NF-KB were measured in terms of fold-change compared to control. Experiments were repeated three times with similar results $(p<0.05)$. Values were expressed as means \pm S.D. \#indicates significant difference in comparison to control group. ${ }^{*} p<0.05$ and ${ }_{* *}^{*} p<0.01$ indicates significant difference in comparison to infected groups. 

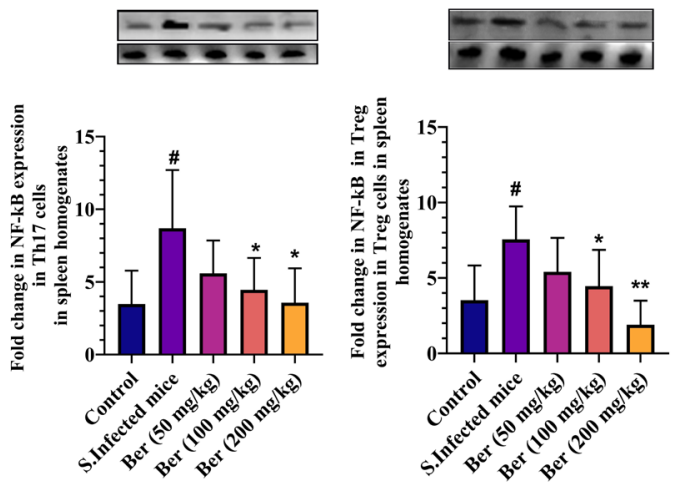

Figure 10. Western blot expression of NF-KB from lysate of Th17 and Treg cells in spleen homogenates.

Schematic expression of NF-KB expression in the FACS isolated Th17 and Treg cells from spleen homogenates. Respective foldchanges in expression are shown in graph. All membranes were stained with anti-beta-tubulin antibody to assure equal protein loading in the gels occurred. Expressions of NF-KB were measured in terms of fold-change compared to control. Experiments were repeated three times with similar results $(p<0.05)$. Values were expressed as means \pm S.D. \#indicates significant difference in comparison to control group. ${ }^{*} p<0.05$ and ${ }^{* *} p<0.01$ indicates significant difference in comparison to infected groups.

\section{Western blot analysis}

In the synovial joints blood and spleen of $S$. aureus infected mice, JNK expression was considerably more in the isolated Th17 cells lysates than in the uninfected group $(\phi<0.05)$ (Fig 7). The 15-day therapy with berberine ( 50 or 100 or $200 \mathrm{mg} / \mathrm{Kg}$ ) revealed significant differences among groups, according to a one-way ANOVA analysis. The post hoc test revealed a substantial decrease in the JNK expression of the Th17 isolated cell lysates from drug-treated mice $(p<0.01)$ when compared to the $S$. aureus-infected group.

The isolated Treg cells expressed JNK (Fig. 7) at a considerably greater level in the diseased group relative to the control group $(p<0.05)$. The one-way ANOVA study of the berberine (50 or 100 or $200 \mathrm{mg} / \mathrm{Kg}$ ) treatments for 15 days revealed significant differences among groups. The post hoc test revealed a substantial decrease in JNK expression in the isolated Treg cells lysates the drug-treated animals $(p<0.01)$ when equaled to the $S$. aureus-infected cluster.

The $\mathrm{NF}-x \mathrm{~B}$ expression was significantly elevated in Th17 cells from the $S$. aureus group in the blood, spleen and synovial joint when compared to the control group $(p<0.05)$ (Fig. 8 and 9). The one-way ANOVA analysis revealed significant differences between groups after 15 days of therapy with berberine (50 or 100 or $200 \mathrm{mg} /$ $\mathrm{Kg})$. In the post hoc test, the expression of $\mathrm{NF}-x \mathrm{~B}$ in Th17 cells of drug-treated mice was considerably lower $(p<0.01)$ than in the $S$. aureus-infected cluster.

Isolated regulatory $\mathrm{T}$ cells (Tregs) from the synovial joints, blood and spleen were also found to express nuclear factor- $x$ B (Fig. 9 and 10). The one-way ANOVA study of the berberine (50 or 100 or $200 \mathrm{mg} / \mathrm{Kg}$ ) treatments for 15 days revealed significant differences among groups. The post hoc test revealed a substantial decrease in NF- $x \mathrm{~B}$ expression in isolated Treg cells of the drugtreated animals $(p<0.01)$ relative to the $S$. aureus infected set of animals.

To find out how bone resorption occurs, we identified the expression of the RANKL in Th17, Treg and CD4+ cells from synovial joints. The $S$. aureus group showed the Th17 cells significantly higher RANKL expression as compared to the control group $(p<0.05)$ (Fig. 11). The 15 -day therapy with berberine (50 or 100 or $200 \mathrm{mg}$ /
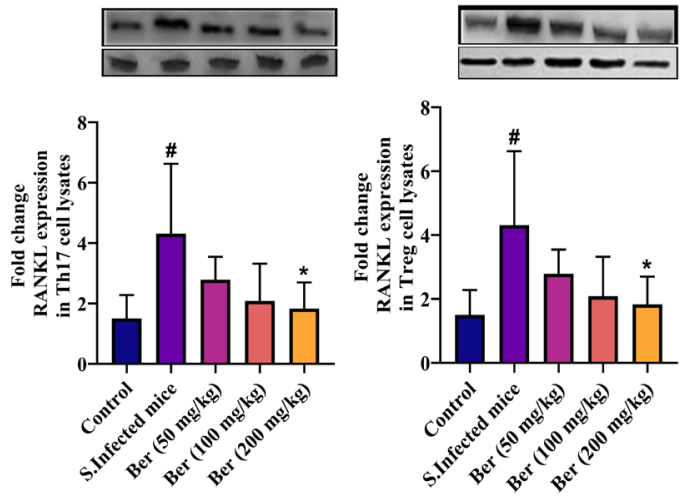

Figure 11. Western blot expression of RANKL from lysate of Th17 and Treg cells in synovial joints.

Schematic expression of RANKL expression in the FACS isolated Th17 and Treg cells from synovial joints. Respective fold-changes in expression are shown in graph. All membranes were stained with anti-beta-tubulin antibody to assure equal protein loading in the gels occurred. Expressions of RANKL were measured in terms of fold-change compared to control. Experiments were repeated three times with similar results $(p<0.05)$. Values were expressed as means \pm S.D. \#indicates significant difference in comparison to control group. ${ }^{*} p<0.05$ and ${ }^{* *} p<0.01$ indicates significant difference in comparison to infected groups.

$\mathrm{Kg}$ ) revealed significant differences among groups, according to a one-way ANOVA analysis. The post hoc test revealed a substantial decrease in the expression of RANKL in Th17, Treg and CD4+ cells from synovial joints of drug-treated animals $(p<0.01)$ relative to the S. aureus-infected cluster.

\section{DISCUSSION}

Because berberine has shown efficacy against numerous microorganisms, such as S. aureus (Chu et al., 2016; Imenshahidi \& Hosseinzadeh, 2016), it is worth testing to see if the drug can be effective in treating $S$. aureusinduced septic arthritis. $S$. aureus was first tested for its sensitivity to berberine in our study. According to the findings, the maximum MIC value in S. aureus (AS-789) was found to be $640 \mu \mathrm{g} / \mathrm{ml}$, and the minimum was found to be $40 \mu \mathrm{g} / \mathrm{ml}$. When $S$. aureus (AS-789) was exposed to berberine, substantial inhibition of growth was observed. The growth evaluation tests indicated that $S$. aureus was sensitive to berberine, which was consistent with the results of the MIC test. In light of these considerations, we propose that the reason for this might be that berberine does not exhibit antibacterial activities contrary to staphylococci by active carnage, but preferably by hampering their growth.

The pathogenic infection triggers an excessive immune response that releases significant quantities of inflammatory cytokines even after the bacteria have been eradicated using modern antibiotic therapies. This leads to joint degeneration and bone resorption (Carpenter et al., 2011). While many additional factors contribute to inflammation of different tissues, staphylococcal antigenicity and bacterial cell-wall components such as toxins, that are highly effective at triggering host immune activation (van Langevelde et al., 1998). Despite advances in medical therapy, septic arthritis continues to be a source of concern because no effective medication has been developed to offset the bone injury caused by the enormous inflammatory response, that finally results in bone disintegration and deterioration of bone function. The development of an effective therapy that can modulate the increased immunological stress and bone degrada- 
tion allied with $S$. aureus-induced septic arthritis is critical. The ability of $S$. aureus to generate and develop septic arthritis necessitates a full understanding of the underlying processes. Our study findings report that joint swelling and arthritis induction greatly improved after treatments with berberine in septic arthritis induced by $S$. aureus in mice. The immunological changes generated by berberine therapies after illness induction are supported by our findings.

T-cell activation and staphylococcal entrance are wellestablished correlations. CD4+ T helper cells are activated as soon as the pathogen enters the body; this creates an immune system that is composed of the innate and adaptive immune systems (Abbas et al., 1996). Th17 cells, a subset of these CD4+ T cells, may have a part in the generation of inflammation in a variety of disorders, including several arthritis models (Zambrano-Zaragoza et al., 2014). Berberine (50, 100 and $200 \mathrm{mg} / \mathrm{Kg}$ ) therapy reduced septic arthritis inflammation by reducing the amount of CD4+ T cells and Th17 cells found in the synovial joints, spleen and blood. Our findings corroborate a previous study in which berberine was shown to alleviate collagen caused arthritis in rats by reducing the responses of Th17 cells (Yue et al., 2017).

To balance the excessive inflammatory milieu, IL-10 secreting T regulatory cells (Fontenot et al., 2003), which aid in immunological tolerance and immune suppression, are abundant. Optimum stability amid Treg and Th17 cells is necessary to preserve homeostasis since a ratio of Th17/Treg imbalance was demonstrated to be associated with the onset, severity of several inflammatory disorders, following the previous study's findings of septic arthritis (Noack \& Miossec, 2014). Treatment with berberine $(50,100$ and $200 \mathrm{mg} / \mathrm{Kg}$ ) improved the balance between Treg and Th17cells, with a lower percentage of Th17 cells with CD4+ and ROR $\gamma$ t and Treg cells with CD4, CD25, FOXp3 indicating feasible down-stream signaling pathways of Treg and Th17 cells with lower IL-21 and TGF- $\beta$ levels in sepsis growth, perseverance. Berberine was shown to improve the equilibrium between Th17 and Treg cells, avoiding sepsis-induced arthritis caused by $S$. aureus for the first time.

The IL-17 produced by Th17 cells binding to its receptor activates the canonical NF-B and MAPK pathways, as well as JNK, and these transcription factors act in concert to increase the transcriptional activation of IL-17 target genes, resulting in chronic inflammation and autoimmune disease (Dey \& Bishayi, 2017). Our study noticed greater levels of $\mathrm{NF}-x \mathrm{~B}$ and $\mathrm{JNK}$ expression in blood and tissues in diseased mice relative to the control group. The increased Th17 cells in a pathogenic environment, thus, may experience downstream signaling via $\mathrm{NF}-x \mathrm{~B}$ and MAPK, which would then exacerbate the current inflammatory process. Treatment with berberine $(50,100$ and $200 \mathrm{mg} / \mathrm{Kg})$ significantly reduced the amount of $\mathrm{NF}-x \mathrm{~B}$ and JNK expression in $S$. aureus ill mice with a lower number of Th17 cells, according to the findings. These findings may be due to lower stimulation of transcriptional IL-17 target genes, involved in the inflammatory responses associated with sepsis-induced arthritis in $S$. aureus-infected animals. The research reported here was consistent with previously gathered data that demonstrates that the impact of berberine on inflammatory cytokines in pig intestinal epithelial cells was that the NF- $x \mathrm{~B} / \mathrm{MAPK}$ signaling pathway's expression had decreased with berberine (Zhu et al., 2020).

The expression of IL-23R in pathogenic Th17 cells can be sustained through IL-23 upregulation, which aids in the continuation of inflammation (Monin \& Gaffen,
2018). NF- $x \mathrm{~B}$ signaling is necessary for the production of the IL-21 gene in T-cells, according to recent research. IL-21 is known to induce $\mathrm{NF}-x \mathrm{~B}$ activity in mice and has been demonstrated to do so in a STAT3dependent manner. We discovered that therapy with berberine $(50,100$ and $200 \mathrm{mg} / \mathrm{Kg}$ ) concluded an insignificant fall in the serum IL-21 and the amount of Th17 cells with reduced NF- $x \mathrm{~B}$ expression in the synovial joints, spleen and blood. Hence, elevated IL-21 levels at the initial stages of infection may be related to enhanced Th17 signaling via the $\mathrm{NF}-x \mathrm{~B}$ and/or JNK signaling pathways. The increased IL-21 signaling, in turn, upregulates $\mathrm{NF}-x \mathrm{~B}$ and JNK signaling, allowing the inflammatory signals to remain and aiding in the persistence of arthritis. Berberine (50, 100 and $200 \mathrm{mg} / \mathrm{Kg}$ ) reduced these elevated levels of IL-21 by lowering Th17 signaling through $\mathrm{NF}-x \mathrm{~B}$ and $\mathrm{JNK}$ signaling pathways, reducing inflammation and $S$. aureus-induced arthritis. Berberine was found to improve intestinal barrier integrity and reduce inflammation, immunosuppression and oxidative stress in deoxynivalenol-challenged piglets in another investigation ( $\mathrm{Zhu}$ et al., 2020).

This validates the pleiotropic involvement of transcriptional factors in T-cell response in sepsis-induced arthritis caused by $S$. aureus-infected mice, which was also observed in our investigation when the highest concentration of Tregs was discovered. The FoxP3 is necessary to sustain Treg immunosuppressive activity via the conventional $\mathrm{NF}-x \mathrm{~B}$ pathway. The results of our study depict, berberine (50, 100 and $200 \mathrm{mg} / \mathrm{Kg}$ ) therapy reduced the Treg population with reduced JNK and NF$x \mathrm{~B}$ in the isolated Treg cells lysates of the blood and tissues, thereby minimizing the transcriptional functions of T-cell responses through lowered immunosuppression of FoxP3 in S. aureus-induced arthritis in mice. The treatment with berberine was also shown to help lower allergic inflammation in a mouse model for house dust mite allergic rhinitis by interfering with immune responses, as it lowered the number of CD4+, CD25+, Foxp3+ Treg cells (Kim et al., 2015).

Hyperactivation of $\mathrm{NF}-x \mathrm{~B}$ was shown to boost TGF- $\beta /$ Smad activation, as it was found that NF- $x \mathrm{~B}$ hyperactivation retained TGF- $\beta / \mathrm{Smad}$ stimulation in humans (Bettelli et al., 2006). TGF- $\beta$ promotes osteoclast survival by activating the nuclear factor $\mathrm{NF}-x \mathrm{~B}$, according to another study (Awasthi et al., 2009). The elevated TGF- $\beta$ level might be a cause for arbitrating osteoclast survival leading to the progress of arthritis. Furthermore, higher JNK expression with increased Treg numbers and TGF- $\beta$ concentration shows the importance of suppressing the functioning of Tregs. This links to the TGF- $\beta$ driven JNK signaling to maintain the regulation of the immune system (Chen et al., 2010).

The berberine (50, 100 and $200 \mathrm{mg} / \mathrm{Kg}$ ) therapy lowered TGF- $\beta$ levels, resulting in less hyperactivation of $\mathrm{NF}-x \mathrm{~B}$ activation. These findings will go a long way in helping to reduce swelling and the continuation of arthritis. Berberine was found to be efficient in reducing Treg function, decreasing TGF- $\beta$ levels and reducing JNK expression in Treg isolated cells. Our findings corroborate previous research demonstrating that berberine protects against bleomycin-induced fibrosis by decreasing NF- $x \mathrm{~B}$ reliant on inflammatory and TGF- $\beta 1$-mediated fibrotic processes (Chitra et al., 2013). The reduced expression of IL-1, IL-6, TGF- $\beta$, TNF- and imparted ICAM-1, as well as the reduced activities of phosphorylated JNK and PNF-B in postoperative abdominal adhesion and inflammation, was also observed in the berberine group, supporting our findings of reduced inflammatory responses 
in sepsis-induced arthritis caused by $S$. aureus (Zhang et al., 2014).

The interplay between RANK and RANKL is a powerful indication of osteoclastogenesis. We measured the expression of RANKL in Th17 cells from synovial joints in our research. It was discovered that SA groups had significantly higher RANKL expression than did the control group. Synovial Th17 cells with elevated RANKL expression are strongly related to mature osteoclast production and bone resorption (Kikuta et al., 2013). Reduced expression of the RANKL in Th17 isolated cells from synovial joints was observed in the treatment groups, lowering the percentages of CD4+ in Th17 isolated cells and reducing osteoclast maturity and bone resorption. The results here are consistent with the other study, which discovered that berberine inhibited osteoclast differentiation via the inhibition of c-Fos and NFATc1 (Han \& Kim, 2019).

Furthermore, IL-17, generated by Th17 cells when they are active, increases NF- $\varkappa \mathrm{B} / \mathrm{JNK}$ signaling, which in turn boosts the expression of RANKL in the osteoblasts and synovial fibroblasts (Vernal \& Garcia-Sanz, 2008). In the existence of macrophage-derived osteotropic factors such as IL-6, TNF- $\alpha$ and IL-1, the interaction of RANK-RANKL causes osteoclast distinction and stimulation, which leads to bone degradation. The generation of IL-17 from activated Th-17 cells was also reduced in our treatment groups, which suppressed NF-B or JNK signaling pathways, which in turn decreased RANKL expression in synovial fibroblasts and osteoclast cells. The treatment effects mitigated the damage caused by osteotropic factors coming from macrophages, such as IL-6, IL-1, or TNF- $\alpha$, by decreasing osteoblast development and activation and so lowering bone degradation.

\section{CONCLUSION}

The berberine $(50,100$ and $200 \mathrm{mg} / \mathrm{Kg}$ ) treatments reduced Th17 cell proliferation and reduced CD4+ T cells induced by staphylococcal superantigenic stimulation, according to our findings. Reduced activity of Th17 cells inhibited the release of pro-inflammatory cytokines, including IL-17, hence suppressing the NF- $x \mathrm{~B} /$ JNK signaling pathways. Further treatment with berberine leads to a decrease in the amount of Treg cells, implying the induction of anti-inflammatory effects via inhibition of NF-B or TGF- $\beta$ driven JNK signaling pathways. According to our findings, reduced IL-21 secretion triggered down-regulation of $\mathrm{NF}-x \mathrm{~B} / \mathrm{JNK}$ signaling and IL-23R in Th17 cells, regulating the duration of inflammatory responses. Furthermore, the treatment groups had lower RANKL expression due to NF- $x \mathrm{~B}$ / JNK signaling downregulation in synovial fibroblasts and osteoblasts. Reduced RANKL expression resulted in decreased osteoclastogenesis, which reduced bone damage and improved arthritic symptoms. A possible strategy for combating disease severity with berberine treatment in $S$. aureus triggered septic arthritis in mice, which targets the Th17 driven NF- $x \mathrm{~B} / \mathrm{JNK}-\mathrm{RANKL}$ axis.

\section{REFERENCES}

Abbas AK, Murphy KM, Sher A (1996) Functional diversity of helper $\mathrm{T}$ lymphocytes. Nature 383: 787-793. https://doi. org $/ 10.1038 / 383787 \mathrm{a} 0$

Arellano B, Graber DJ, Sentman CL (2016) Regulatory T cell-based therapies for autoimmunity. Discov Med. 22: 73-80

Awasthi A, Riol-Blanco L, Jäger A, Korn T, Pot C, Galileos G, Oukka M (2009) Cutting edge: IL-23 receptor gfp reporter mice reveal distinct populations of IL-17-producing cells. I Immunol 182: 5904 5908. https://doi.org/10.4049/jimmunol.0900732

Ayati SH, Fazeli B, Momtazi-Borojeni AA, Cicero AFG, Pirro M, Sahebkar A (2017) Regulatory effects of berberine on microRNome in cancer and other conditions. Crit Rev Oncol Hematol 116: 147-158. https://doi.org/10.1016/j.critrevonc.2017.05.008

Beringer A, Noack M, Miossec P (2016) IL-17 in Chronic inflammation: from discovery to targeting. Trends Mol Med 22: 230-241. https://doi.org/10.1016/j.molmed.2016.01.001

Bettelli E, Carrier Y, Gao W, Korn T, Strom TB, Oukka M, Kuchroo VK (2006) Reciprocal developmental pathways for the generation of pathogenic effector TH17 and regulatory T cells. Nature 441: 235-238. https://doi.org/10.1038/nature04753

Bettelli E, Korn T, Oukka M, Kuchroo VK (2008) Induction and effector functions of $\mathrm{T}(\mathrm{H}) 17$ cells. Nature 453: 1051-1057. https:// doi.org/10.1038/nature07036

Carpenter CR, Schuur JD, Everett WW, Pines JM (2011) Evidencebased diagnostics: adult septic arthritis. Acad Emerg Med 18: $781-$ 796. https://doi.org/10.1111/j.1553-2712.2011.01121.x

Chang JH, Xiao Y, Hu H, Jin J, Yu J, Zhou X, Sun SC (2012) Ubc13 maintains the suppressive function of regulatory $\mathrm{T}$ cells and prevents their conversion into effector-like T cells. Nat Immunol 13: 481-490. https://doi.org/10.1038/ni.2267

Chang M, Lee AJ, Fitzpatrick L, Zhang M, Sun SC (2009). NF-kappa B1 p105 regulates $T$ cell homeostasis and prevents chronic inflammation. I Immunol 182: 3131-3138. https://doi.org/10.4049/jimmunol.0803637

Chen G, Hardy K, Bunting K, Daley S, Ma L, Shannon MF (2010) Regulation of the IL-21 gene by the NF- $x \mathrm{~B}$ transcription factor c-Rel. J Immunol 185: 2350-2359. https://doi.org/10.4049/jimmunol.1000317

Chen Y, Bai P, Liu L, Han J, Zeng H, Sun Y (2016) Increased RANKL expression in peripheral $\mathrm{T}$ cells is associated with decreased bone mineral density in patients with COPD. Int J Mol Med 38: 585-593. https://doi.org/10.3892/ijmm.2016.2629

Chitra P, Saiprasad G, Manikandan R, Sudhandiran G (2013) Berberine attenuates bleomycin induced pulmonary toxicity and fibrosis via suppressing NF- $x \mathrm{~B}$ dependant TGF- $\beta$ activation: a biphasic experimental study. Toxicol Lett 219: 178-193. https://doi.org/10.1016/j. toxlet.2013.03.009

Chu M, Zhang MB, Liu YC, Kang JR, Chu ZY, Yin KL, Wang YD (2016) Role of berberine in the treatment of methicillin-resistant Staphylococcus aureus Infections. Sci Rep 6: 24748. https://doi. org/10.1038/srep24748

Cicero AF, Baggioni A (2016) Berberine and its role in chronic disease. Adv Exp Med Biol 928: 27-45. https://doi.org/10.1007/978-3-31941334-1_2

Colavite-Machado PM, Ishikawa LL, França TG, Zorzella-Pezavento SF, da Rosa LC, Chiuso-Minicucci F, Sartori A (2013) Differential arthritogenicity of Staphylococcus aureus strains isolated from biological samples. BMC Infect Dis 13: 400. https://doi.org/10.1186/14712334-13-400

Dey I, Bishayi B (2017) Role of Th17 and Treg cells in septic arthritis and the impact of the Th17/Treg-derived cytokines in the pathogenesis of $S$. aureus induced septic arthritis in mice. Microb Pathog 113: 248-264. https://doi.org/10.1016/j.micpath.2017.10.033

Dey I, Bishayi B (2020) Impact of simultaneous neutralization of IL$17 \mathrm{~A}$ and treatment with recombinant IL-2 on Th17-Treg cell population in S. aureus-induced septic arthritis. Microb Pathog 139: 103903. https://doi.org/10.1016/j.micpath.2019.103903

Dinesh P, Rasool M (2018) Berberine inhibits IL-21/IL-21R mediated inflammatory proliferation of fibroblast-like synoviocytes through the attenuation of PI3K/Akt signaling pathway and ameliorates IL21 mediated osteoclastogenesis. Cytokine 106: 54-66. https://doi. org/10.1016/j.cyto.2018.03.005

Dinesh P, Rasool M (2019) Berberine mitigates IL-21/IL-21R mediated autophagic influx in fibroblast-like synoviocytes and regulates Th17/Treg imbalance in rheumatoid arthritis. Apoptosis 24: 644-661. https://doi.org/10.1007/s10495-019-01548-6

Dominguez-Villar M, Hafler DA (2018) Regulatory T cells in autoimmune disease. Nat Immunol 19: 665-673. https://doi.org/10.1038/ s41590-018-0120-4

Dong C, Yang DD, Tournier C, Whitmarsh AJ, Xu J, Davis RJ, Flavell RA (2000) JNK is required for effector T-cell function but not for T-cell activation. Nature 405: 91-94. https://doi. org/10.1038/35011091

Fatahian A, Haftcheshmeh SM, Azhdari S, Farshchi HK, Nikfar B, Momtazi-Borojeni AA (2020) Promising anti-atherosclerotic effect of berberine: evidence from in vitro, in vivo, and clinical studies. Rev Physiol Biochem Pharmacol 178: 83-110. https://doi. org/10.1007/112_2020_42

Fontenot JD, Gavin MA, Rudensky AY (2003) Foxp3 programs the development and function of CD $4+\mathrm{CD} 25+$ regulatory $\mathrm{T}$ cells. Nat Immunol 4: 330-336. https://doi.org/10.1038/ni904

Grant CR, Liberal R, Mieli-Vergani G, Vergani D, Longhi MS (2015) Regulatory T-cells in autoimmune diseases: challenges, controversies 
and - yet - unanswered questions. Autoimmun Rev 14: 105-116. https://doi.org/10.1016/j.autrev.2014.10.012

Greve B, Weissert R, Hamdi N, Bettelli E, Sobel RA, Coyle A, Schmidt-Supprian M (2007) I kappa B kinase 2/beta deficiency controls expansion of autoreactive $\mathrm{T}$ cells and suppresses experimental autoimmune encephalomyelitis. J Immunol 179: 179-185. https://doi. org/10.4049/jimmunol.179.1.179

Guo N, Zhao X, Li W, Shi C, Meng R, Liu Z, Yu L (2015) The synergy of berberine chloride and totarol against Staphylococcus aureus grown in planktonic and biofilm cultures. J Med Microbiol 64: 891900. https://doi.org/10.1099/jmm.0.000106

Han SY, Kim YK (2019) Berberine suppresses RANKL-induced osteoclast differentiation by inhibiting c-Fos and NFATc1 expression. Am J Chin Med 47: 439-455. https://doi.org/10.1142/ s0192415x19500228

Henningsson L, Jirholt P, Lindholm C, Eneljung T, Silverpil E, Iwakura Y, Gjertsson I (2010) Interleukin-17A during local and systemic Staphylococcus aureus-induced arthritis in mice. Infect Immun 78: 37833790. https://doi.org/10.1128/iai.00385-10

Hu JP, Nishishita K, Sakai E, Yoshida H, Kato Y, Tsukuba T, Okamoto K (2008) Berberine inhibits RANKL-induced osteoclast formation and survival through suppressing the NF-kappaB and Akt pathways. Eur J Pharmacol 580: 70-79. https://doi.org/10.1016/j. ejphar.2007.11.013

Hu Z, Jiao Q, Ding J, Liu F, Liu R, Shan L, Zhang W (2011) Berberine induces dendritic cell apoptosis and has therapeutic potential for rheumatoid arthritis. Arthritis Rheum 63: 949-959. https://doi. org/10.1002/art.30202

Huber M, Brüstle A, Reinhard K, Guralnik A, Walter G, Mahiny A, Lohoff M (2008) IRF4 is essential for IL-21-mediated induction, amplification, and stabilization of the Th17 phenotype. Proc Natl Acad Sci USA 105: 20846-20851. https://doi.org/10.1073/ pnas.0809077106

Ichiyama K, Sekiya T, Inoue N, Tamiya T, Kashiwagi I, Kimura A, Yoshimura A (2011) Transcription factor Smad-independent T helper 17 cell induction by transforming-growth factor- $\beta$ is mediated by suppression of eomesodermin. Immunity 34: 741-754. https://doi. org/10.1016/j.immuni.2011.02.021

Imenshahidi M, Hosseinzadeh H (2016) Berberis vulgaris and berberine: An update review. Phytother Res 30: 1745-1764. https://doi. org/10.1002/ptr.5693

Johansen KS, Johansen TS, Talmage DW (1974) T cell rosette formation in primates, pigs, and guinea pigs. The influence of immunosuppressive agents. J Allergy Clin Immunol 54: 86-93. https://doi. org/10.1016/0091-6749(74)90036-0

Kikuta J, Wada Y, Kowada T, Wang Z, Sun-Wada GH, Nishiyama I, Ishii M (2013) Dynamic visualization of RANKL and Th17-mediated osteoclast function. J Clin Invest 123: 866-873. https://doi. org/10.1172/jci65054

Kim BY, Park HR, Jeong HG, Kim SW (2015) Berberine reduce allergic inflammation in a house dust mite allergic rhinitis mouse model. Rhinology 53: 353-358. https://doi.org/10.4193/Rhino15.028

Kimura A, Kishimoto T (2010) IL-6: regulator of Treg/Th17 balance. Eur J Immunol 40: 1830-1835. https://doi.org/10.1002/ eji.201040391

Kong N, Lan Q, Chen M, Wang J, Shi W, Horwitz D A, Zheng SG (2012) Antigen-specific transforming growth factor $\beta$-induced Treg cells, but not natural Treg cells, ameliorate autoimmune arthritis in mice by shifting the Th17/Treg cell balance from Th17 predominance to Treg cell predominance. Arthritis Rheum 64: 2548-2558. https://doi.org/10.1002/art.34513

Kugyelka R, Kohl Z, Olasz K, Mikecz K, Rauch TA, Glant T. T., \& Boldizsar, F (2016) Enigma of IL-17 and Th17 cells in rheumatoid arthritis and in autoimmune animal models of arthritis. Mediators Inflamm 2016: 6145810. https://doi.org/10.1155/2016/6145810

Kumar A, Ekavali Chopra K, Mukherjee M, Pottabathini R, Dhull DK (2015) Current knowledge and pharmacological profile of berberine: An update. Eur J Pharmacol 761: 288-297. https://doi.org/10.1016/j. ejphar.2015.05.068

Li JK, Nie L, Zhao YP, Zhang YQ, Wang X, Wang SS, Cheng L (2016) IL-17 mediates inflammatory reactions via $\mathrm{p} 38 / \mathrm{c}-\mathrm{Fos}$ and JNK/c-Jun activation in an AP-1-dependent manner in human nucleus pulposus cells. J Transl Med 14: 77. https://doi.org/10.1186/ s12967-016-0833-9

Li YS, Deng ZH, Zeng C, Lei GH (2016) JNK pathway in osteosarcoma: pathogenesis and therapeutics. I Recept Signal Transduct Res 36: 465-470. https://doi.org/10.3109/10799893.2015.1122045

Long M, Park SG, Strickland I, Hayden MS, Ghosh S (2009) Nuclear factor-kappaB modulates regulatory $\mathrm{T}$ cell development by directly regulating expression of Foxp3 transcription factor. Immunity 31: 921-931. https://doi.org/10.1016/j.immuni.2009.09.022

Lu L, Ma J, Wang X, Wang J, Zhang F, Yu J, Zheng SG (2010) Synergistic effect of TGF-beta superfamily members on the induction of Foxp3+ Treg. Eur J Immunol 40: 142-152. https://doi.org/10.1002/ eji.200939618
Lubberts E (2010) Th17 cytokines and arthritis. Semin Immunopathol 32: 43-53. https://doi.org/10.1007/s00281-009-0189-9

Majhi A, Kundu K, Adhikary R, Banerjee M, Mahanti S, Basu A, Bishayi B (2014) Combination therapy with ampicillin and azithromycin in an experimental pneumococcal pneumonia is bactericidal and effective in down regulating inflammation in mice. J Inflamm (Lond) 11: 5. https://doi.org/10.1186/1476-9255-11-5

Mizobe F, Martial E, Colby-Germinario S, Livett BG (1982) An improved technique for the isolation of lymphocytes from small volumes of peripheral mouse blood. J Immunol Methods 48: 269-279. https://doi.org/10.1016/0022-1759(82)90327-1

Monin L, Gaffen SL (2018) Interleukin 17 family cytokines: signaling mechanisms, biological activities, and therapeutic implications. Cold Spring Harb Perspect Biol 10: https://doi.org/10.1101/cshperspect. a028522

Moreland LW, Curtis JR (2009) Systemic nonarticular manifestations of rheumatoid arthritis: focus on inflammatory mechanisms. Semin Arthritis Rheum 39: 132-143. https://doi.org/10.1016/j.semarthrit.2008.08.003

Mortazavi H, Nikfar B, Esmaeili SA, Rafieenia F, Saburi E, Chaichian S, Momtazi-Borojenib AA (2020) Potential cytotoxic and anti-metastatic effects of berberine on gynaecological cancers with drug-associated resistance. Eur J Med Chem 187: 111951. https://doi. org/10.1016/j.ejmech.2019.111951

Noack M, Miossec P (2014) Th17 and regulatory T cell balance in autoimmune and inflammatory diseases. Autoimmun Rev 13: 668-677. https://doi.org/10.1016/j.autrev.2013.12.004

Oh H, Ghosh S (2013). NF-xB: roles and regulation in different CD4(+) T-cell subsets. Immunol Rev. 252: 41-51. https://doi. org/10.1111/imr.12033

Puliti M, von Hunolstein C, Bistoni F, Castronari R, Orefici G, Tissi L (2002) Role of macrophages in experimental group B streptococcal arthritis. Cell Microbiol 4: 691-700. https://doi.org/10.1046/j.14625822.2002.00223.x

Rampersad RR, Tarrant TK, Vallanat CT, Quintero-Matthews T, Weeks MF, Esserman, DA, Liu P (2011) Enhanced Th17-cell responses render CCR2-deficient mice more susceptible for autoimmune arthritis. PLoS One 6: e25833. https://doi.org/10.1371/journal.pone.0025833

Ruan Q, Chen YH (2012) Nuclear factor- $x$ B in immunity and inflammation: the Treg and Th17 connection. Adv Exp Med Biol 946: 207221. https://doi.org/10.1007/978-1-4614-0106-3_12

Ruan Q, Kameswaran V, Tone Y, Li L, Liou HC, Greene MI, Chen YH (2009) Development of Foxp3(+) regulatory t cells is driven by the c-Rel enhanceosome. Immunity 31: 932-940. https://doi. org/10.1016/j.immuni.2009.10.006

Sato K, Suematsu A, Okamoto K, Yamaguchi A, Morishita Y, Kadono Y, Takayanagi H (2006) Th17 functions as an osteoclastogen ic helper $\mathrm{T}$ cell subset that links $\mathrm{T}$ cell activation and bone destruction. J Exp Med 203: 2673-2682. https://doi.org/10.1084/ jem. 20061775

Shi JH, Sun SC (2015) TCR signaling to NF- $x$ B and mTORC1: Expanding roles of the CARMA1 complex. Mol Immunol 68: 546-557. https://doi.org/10.1016/j.molimm.2015.07.024

Shirtliff ME, Mader JT (2002) Acute septic arthritis. Clin Microbiol Rev 15: 527-544. https://doi.org/10.1128/cmr.15.4.527-544.2002

Somayaji SN, Ritchie S, Sahraei M, Marriott I, Hudson, M. C. (2008). Staphylococcus aureus induces expression of receptor activator of NF-kappaB ligand and prostaglandin E2 in infected murine osteoblasts. Infect Immun 76: 5120-5126. https://doi.org/10.1128/ iai.00228-08

Sujitha S, Dinesh P, Rasool M (2020). Berberine encapsulated PEGcoated liposomes attenuate $\mathrm{Wnt} 1 / \beta$-catenin signaling in rheumatoid arthritis via miR-23a activation. Eur J Pharm Biopharm 149: 170-191. https://doi.org/10.1016/j.ejpb.2020.02.007

Sun SC (2011) Non-canonical NF-xB signaling pathway. Cell Res 21: 71-85. https://doi.org/10.1038/cr.2010.177

Takayanagi H (2005). Inflammatory bone destruction and osteoimmunology. I Periodontal Res 40: 287-293. https://doi.org/10.1111/ j.1600-0765.2005.00814.x

Vallabhapurapu S, Karin M (2009) Regulation and function of NFkappaB transcription factors in the immune system. Annu Rev Immunol 27: 693-733. https://doi.org/10.1146/annurev.immunol.021908.132641

van Langevelde P, van Dissel JT, Ravensbergen E, Appelmelk BJ, Schrijver IA, Groeneveld PH (1998) Antibiotic-induced release of lipoteichoic acid and peptidoglycan from Staphylococcus aureus: quantitative measurements and biological reactivities. Antimicrob Agents Chemother 42: 3073-3078. https:/ /doi.org/10.1128/aac.42.12.3073

Vernal R, Garcia-Sanz JA (2008). Th17 and Treg cells, two new lymphocyte subpopulations with a key role in the immune response against infection. Infect Disord Drug Targets 8: 207-220. https://doi. org/10.2174/187152608786734197

Wang Z, Chen Z, Yang S, Wang Y, Huang Z, Gao J, Rao Z (2014) Berberine ameliorates collagen-induced arthritis in rats associated 
with anti-inflammatory and anti-angiogenic effects. Inflammation 37 : 1789-1798. https://doi.org/10.1007/s10753-014-9909-y

Wilde B, Thewissen M, Damoiseaux J, Hilhorst M, van Paassen P, Witzke O, Cohen Tervaert JW (2012). Th17 expansion in granulomatosis with polyangiitis (Wegener's): the role of disease activity, immune regulation and therapy. Arthritis Res Ther 14: R227. https:// doi.org/10.1186/ar4066

Yue M, Xia Y, Shi C, Guan C, Li Y, Liu R, Dai Y (2017) Berberine ameliorates collagen-induced arthritis in rats by suppressing Th17 cell responses via inducing cortistatin in the gut. FEBS J 284: 27862801. https://doi.org/10.1111/febs.14147

Zambrano-Zaragoza JF, Romo-Martínez EJ, Durán-Avelar Mde J, García-Magallanes N, Vibanco-Pérez N (2014) Th17 cells in autoimmune and infectious diseases. Int I Inflam 23: 651503. https://doi. $\operatorname{org} / 10.1155 / 2014 / 651503$
Zhang Y, Li X, Zhang Q, Li J, Ju J, Du N, Yang B (2014) Berberine hydrochloride prevents postsurgery intestinal adhesion and inflammation in rats. J Pharmacol Exp Ther 349: 417-426. https://doi. org/10.1124/jpet.114.212795

Zhang YE (2009) Non-Smad pathways in TGF-beta signaling. Cell Res 19: 128-139. https://doi.org/10.1038/cr.2008.328

Zhou J, Yu Y, Yang X, Wang Y, Song Y, Wang Q, Wei F (2019) Berberine attenuates arthritis in adjuvant-induced arthritic rats associated with regulating polarization of macrophages through AMPK/NF-кB pathway. Eur J Pharmacol 852: 179-188. https://doi. org/10.1016/j.ejphar.2019.02.036

Zhu Z, Xueying L, Chunlin L, Wen X, Rongrong Z, Jing H, Zili W (2020) Effect of berberine on LPS-induced expression of NF- $x \mathrm{~B} /$ MAPK signaling pathway and related inflammatory cytokines in porcine intestinal epithelial cells. Innate Immun. 26: 627-634. https:// doi.org/10.1177/1753425920930074 